\title{
THE MODERATING EFFECT OF LEADER ANGER ON THE RELATIONSHIP BETWEEN LEADER-MEMBER EXCHANGE AND FOLLOWER JOB OUTCOMES
}

Nevra BAKER ${ }^{1}$

\author{
Received (Başvuru Tarihi): 03/04/2019 \\ Accepted (Kabul Tarihi): 29/04/2019 \\ Published Date (Yayın Tarihi): 26/06/2019
}

\begin{abstract}
This study investigates the moderating effect of leader anger on the relationship between LMX, which is one of the most prominent leadership theories, and the three follower job outcomes of affective commitment towards the organization, trust in leader, and job satisfaction. This study was undertaken in the format of an experiment which is followed by a survey in which four groups of different fictional leader types were created, and respondents were asked to answer questions about these leaders assuming that they work with the described leader. The results of the study reveal that leader anger moderates the relationship between leader-member exchange and the three follower job outcomes in such a way that they result in diminished levels of affective commitment towards the organization, trust in leader, and job satisfaction in cases of both high LMX and low LMX leaders.
\end{abstract}

Keywords: Leader-Member Exchange, Affective Commitment, Trust In Leader, Job Satisfaction, Anger

JEL Codes: L2O, M10

\section{LIDER ÖFKESINIIN LIDER-ÜYE ETKILLEŞIMİ VE TAKIPPÇI IŞS SONUÇLARI ARASINDAKİ İLIŞKİ ÜZERINE MODERE EDİCI ETKİSi}

$\ddot{O} Z$

Bu çalışma, lider öfke duygu dlşavurumunun, lider-üye etkileşimi ve takipçi iş sonuçlarından örgütsel duygusal bağlllık, lidere güven ve iş memnuniyeti arasındaki ilişki üzerine modere edici etkisini araştırmaktadır. Bu çalışma, deney ve peşinden gelen anket formatında düzenlenmiştir. Deney formatında, dört farkl kurgusal lider tipi oluşturulmuştur ve daha sonraki gelen ankette, katılımcılardan, tarif edilen liderlerle çalıştıklarını varsayarak bu liderler hakkındaki soruları cevaplamaları istenmişstir. Bu çalışmanın sonuçlarına göre, lider öfke duygu dışavurumu hem yüksek derecede hem de alçak derecede lider-üye etkileşimi sergileyen liderler için, daha düşük örgütsel duygusal bağlllık, daha düşük lidere güven ve daha düşük iş memnuniyetine yol açarak, lider-üye etkileşimi ve takipçi iş sonuçları arasındaki ilişskiyi modere eder.

Anahtar Kelimeler: Lider-Üye Etkileşimi, Duygusal Bağlllık, Lidere Güven, İş Memnuniyeti, Öfke

JEL Kodları: L20, M10

${ }^{1}$ Dr. Öğretim Üyesi, Altınbaş Üniversitesi, nevra.baker@altinbas.edu.tr 


\section{INTRODUCTION}

Leader-member exchange theory (LMX) is a leadership theory that deals with the quality of interactions between leaders and their followers. Accordingly, we can speak of two kinds of interactions, the in-group and the out-group. Subordinates in the in-group take on more responsibilities than are stated in their job engage in more activities than are stated in their formal employment contract. Therefore, they receive more attention, resources, and support from their leaders. On the other hand, employees who belong to the out-group are not willing to engage in extra activities which are not stated in their employment contract. They just do what is expected from them and not more. Therefore, they do not receive as much support and resources from their leaders as their peers in the in-group. According to the LMX theory, the leader-follower transactions between leaders and in-group followers are of higher quality than those between leaders and followers in the out-group (Dansereau, Graen, \& Haga, 1975).

Emotions can be found in almost every leader-follower transaction. Emotions stem from these transactions and they also influence these transactions (Sy, Côté, \& Saavedra, 2005). Because leaders can strongly affect how organizations and their members function (Yukl, 2005), leader emotional expressions have a substantial ability to influence how these members feel (George, 2000). Emotions can be grouped into positive and negative emotions. Among positive emotions, one can cite happiness, love, serenity, optimism, and hope. On the other hand, anger, guilt, and frustration are examples of negative emotions.

Earlier studies have investigated the relationship between leader-member exchange theory and the follower job outcomes of affective commitment towards the organization (e.g., Şirin, 2012; Ülker, 2015), trust in leader (e.g., Baker, 2018), and job satisfaction (e.g., Bulut, 2012; Akkaya, 2015). In this study, the author aims to find out how the expression of anger by the leaders affects the relationship between leader-member exchange and the three job outcomes.

\section{LITERATURE REVIEW AND HYPOTHESIS DEVELOPMENT}

\subsection{The Moderating Effect of Anger on the Relationship between LMX and} Follower Affective Commitment

Anger brings about less favorable social or correctable behaviors. For instance, anger expressions engender lower levels of collaboration than discontented expressions (Wubben et al., 2009) and arouse vindictive actions (Van Kleef and Cote, 2007). Indeed, whether aroused 
by angry expressions or not, angry persons have an inclination towards vindictive actions (Gibson and Callister, 2010), for instance hostility, alienated behaviors and abstention from the person who caused the anger (Fitness, 2000). By the same token, by cause of the otherattributing characteristic of anger, angry persons are inclined to blame others more (Lerner and Tiedens, 2006). Allen and Meyer (1990) defined affective organizational commitment as the employee's positive sentimental adherence to and identification with the organization. The author assumes that such positive sentimental adherence of followers cannot take place if they feel alienation and abstention towards their angry leader. In addition, the author thinks that it should be difficult for followers to identify with a leader who has an inclination to put blame on others. As empirical evidence, a study by Van Kleef et al. (2009) showed that work teams that were operating with angry leaders cultivated negative feelings and lower levels of affinity with these leaders. Thus, the author proposes that the expressivity of anger by the leader should impoverish the contribution of leader-member exchange on follower affective commitment. Thus, the author came up with the hypotheses below:

H1. Negative emotional expressions by the leader (e.g. anger) moderate the relationship between LMX and follower affective commitment, where LMX leaders who display negative emotional expressions will arouse less affective commitment by their followers as compared to high LMX leaders who do not.

H2. Negative emotional expressions by the leader (e.g. anger) moderate the relationship between LMX and follower affective commitment, where low LMX leaders who display negative emotional expressions will arouse less affective commitment by their followers as compared to low LMX leaders who do not.

\subsection{The Moderating Effect of Anger on the Relationship between LMX and} Follower Trust In Leader

Displaying anger will be recognized as being apart from leader role ideals (Rafaeli and Sutton, 1987), symbolizing a deficiency in emotional control (Goleman, 1998), and indicating an inadequacy of self-confidence (Kirkpatrick and Locke, 1991). Expression of anger conveying accusation and accountability of others for a negative incident (Lerner and Tiedens, 2006) can be sensed as unearned and be the initiator of anger backlashes (Elfenbein, 2007), and aggressive anger expression general evokes mutual anger (Lelieveld et al., 2012). The fact that the expression of anger by a leader can be sensed as unearned contradicts with the definition of trust as a "psychological state comprising the intention to accept vulnerability based upon 
positive expectations of the intentions or behavior of another" (Rousseau et al., 1998, p. 395) because the author assumes that followers will not be in a state to accept vulnerability if they feel that they are being accused. As empirical evidence, studies have indicated that anger decreases the quality of the social atmosphere and gives rise to the emergence of negative feelings (Tiedens, 2001; Van Kleef, 2009), along with a decrease in trust (Lerner and Tiedens, 2006). Also, research asserts that when followers sense that a leader's emotional displays are unsuitable, this diminishes their trust in the leader (Gardner, Fischer, \&Hunt, 2009). In line with the above discussion, the author put forth that the expressivity of anger by leaders should weaken the contribution of leader-member exchange on follower trust in leadership. Thus, the author came up with the following hypotheses:

H3. Negative emotional expressions by the leader (e.g. anger) moderate the relationship between LMX and follower trust in leader, where high LMX leaders who display negative emotional expressions will arouse less trust by their followers as compared to high LMX leaders who do not.

H4. Negative emotional expressions by the leader (e.g. anger) moderate the relationship between LMX and follower trust in leader, where low LMX leaders who display negative emotional expressions will arouse less trust by their followers as compared to low LMX leaders who do not.

\subsection{The Moderating Effect of Anger on the Relationship between LMX and} Follower Job Satisfaction

Dasborough's (2006) qualitative research manifests that employees remembered more adverse affective incidents relating to their leaders than favorable ones. Anger in leadership studies has been associated with sensations of un-inspirational leadership (Waldman et al., 2011), narrow-minded leader despotism (Kant et al., 2013) or witness sensations of diminished leader effectiveness (Lewis, 2000). Job satisfaction has been portrayed as a "pleasurable or positive emotional state resulting from the appraisal of one's job or job experiences" (Locke, 1976). As empirical evidence, Glomb and Hulin (1997) discovered that disregarding gender, leaders displaying anger when dealing with an employee were graded lower in effectiveness and satisfaction with supervisor. Therefore, the author supposes that the expressivity of anger by leaders should impair the contribution of leader-member exchange on follower job satisfaction. Thus, the author proposes the following hypotheses: 
H5. Negative emotional expressions by the leader (e.g. anger) moderate the relationship between LMX and follower job satisfaction, where high LMX leaders who display negative emotional expressions will arouse less job satisfaction by their followers as compared to high LMX leaders who do not.

H6. Negative emotional expressions by the leader (e.g. anger) moderate the relationship between LMX and follower job satisfaction, where low LMX leaders who display negative emotional expressions will arouse less job satisfaction by their followers as compared to low LMX leaders who do not.

\section{METHODOLOGY}

\subsection{Research Design}

This study aims to test the moderation of leader anger on the relationship between leader-member exchange and the job outcomes of affective commitment, trust in leadership, and job satisfaction. The model depicting the hypothetical relationships is presented in Figure 1.

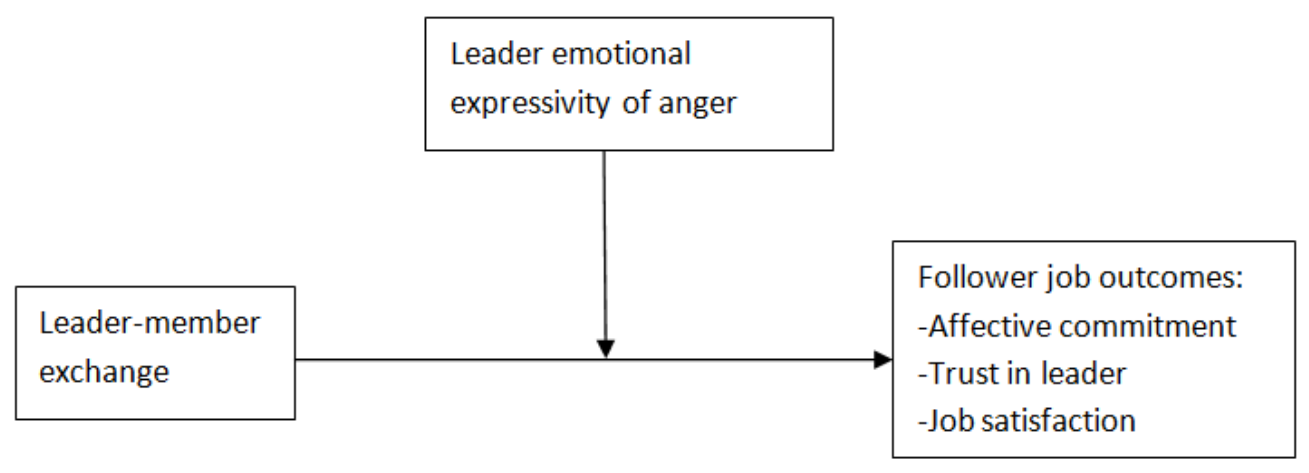

Figure 1: Conceptual Model of the Study

This study was undertaken in the format of an experiment. Four $2 * 2$ experiments were carried out in separate groups consisting of at least 10 persons. Each experiment was composed of two paragraphs. The first paragraph described a fictional high LMX leader or a fictional low LMX leader. The second paragraph described the same leader expressing anger or being neutral. In order to describe leader-member exchange, the items of the LMX-7 scale developed by Graen and Uhl-Bien (1995), and in order to describe anger, adaptable items of the Spielberger's Stait-Trait Anger Expression Inventory (1988) were used, respectively. In order to make descriptions, the scale items of related scales were translated to Turkish. After reading 
the two paragraphs, the participants were given a survey so that they would be able to rate their own level of potential affective commitment to the organization, trust in that fictional leader, and job satisfaction, assuming that the fictional leader was their actual leader. This survey contained the items of the Affective Commitment Scale by Meyer et al. (1993), Trust in Supervisor Scale by Inelmen (2009), and the shorter version of by Brayfield \& Rothe's (1951) job satisfaction scale, which was shortened to a five-item scale by Judge, Locke, Durham, \& Kluger (1998).

\subsection{Sample}

A total of 52 employees working in the services industry were contacted, making up 4 different groups. The average age of the employees is 27.1, ranging from 18 to 46.33 (63.5\%) of the contacted employees are male. $6(11.5 \%)$ of the contacted employees attended only elementary school, 31 (59.6\%) are high school graduates, 13 (25\%) attended university, and 2 $(3.8 \%)$ completed higher education. The average working years add up to 7.0, ranging from 1 to 25 . The average tenure of the respondents is 3.4 years, ranging from a minimum of 1 to a maximum of 25 years. $11(21.2 \%)$ of the total of 52 respondents are from the finance industry, again $11(21.2 \%)$ work in the retail industry, 7 (13.5\%) come from the food industry, again 7 $(13.5 \%)$ work in the customer services sector, 5 (9.6\%) are from the transportation sector, and the remaining 11 respondents $(21.2 \%)$ are from other services industries such as tourism, education, and real estate.

\subsection{Hypothesis Testing}

For this study, 4 groups of different fictional leader types were created, and respondents were asked to answer questions about these leaders assuming that they work with the described leader.

Because there are two independent samples in this study, and the measurement level is ratio, independent samples t-test is used to analyze the differences between groups in terms of the dependent variables of follower affective commitment, trust in leader, and job satisfaction.

Table 1 and Table 2 show the group statistics and the independent samples t-test results for Group 1 and Group 2: 
Table 1. Group Statistics for Group 1 (Angry High LMX Leader) and Group 2 (Non-Angry High LMX Leader)

\begin{tabular}{llcccr}
\hline Dependent variables & \multicolumn{1}{c}{ Groups } & N & Mean & Std. Deviation & Std. Error Mean \\
\hline \multirow{2}{*}{$\begin{array}{l}\text { Affective } \\
\text { commitment }\end{array}$} & $\begin{array}{l}\text { Angry high LMX } \\
\text { leader }\end{array}$ & 13 & 3.16 & .63 & .17 \\
\cline { 2 - 6 } & $\begin{array}{l}\text { Non-angry high } \\
\text { LMX leader }\end{array}$ & 13 & 4.41 & .12 & .03 \\
\hline \multirow{2}{*}{ Trust in leader } & $\begin{array}{l}\text { Angry high LMX } \\
\text { leader }\end{array}$ & 13 & 3.28 & .77 & .21 \\
\cline { 2 - 6 } & $\begin{array}{l}\text { Non-angry high } \\
\text { LMX leader }\end{array}$ & 13 & 4.49 & .19 & .05 \\
\hline \multirow{2}{*}{ Job satisfaction } & $\begin{array}{l}\text { Angry high LMX } \\
\text { leader }\end{array}$ & 13 & 3.43 & .79 & .22 \\
\cline { 2 - 6 } & $\begin{array}{l}\text { Non-angry high } \\
\text { LMX leader }\end{array}$ & 13 & 4.11 & .38 & .11 \\
\hline
\end{tabular}

Table 2. Independent Samples t-Test Results for Group 1 (Angry High LMX Leader) and Group 2 (Non-Angry High LMX Leader)

\begin{tabular}{|c|c|c|c|c|c|c|c|c|c|c|}
\hline & & \multicolumn{2}{|c|}{$\begin{array}{l}\text { Levene's Test } \\
\text { for Equality } \\
\text { of Variances }\end{array}$} & \multicolumn{7}{|c|}{ t-test for Equality of Means } \\
\hline & & \multirow[t]{2}{*}{$\mathrm{F}$} & \multirow[t]{2}{*}{ Sig. } & \multirow[t]{2}{*}{$\mathrm{t}$} & \multirow[t]{2}{*}{ df } & \multirow[t]{2}{*}{$\begin{array}{l}\text { Sig. (2- } \\
\text { tailed) }\end{array}$} & \multirow[t]{2}{*}{$\begin{array}{l}\text { Mean } \\
\text { Diff. }\end{array}$} & \multirow[t]{2}{*}{$\begin{array}{l}\text { Std. } \\
\text { Error } \\
\text { Diff. }\end{array}$} & \multicolumn{2}{|c|}{$\begin{array}{l}\text { 95\% Confidence } \\
\text { Interval of the } \\
\text { Difference }\end{array}$} \\
\hline & & & & & & & & & Lower & Upper \\
\hline \multirow{2}{*}{$\begin{array}{l}\text { Affective } \\
\text { commitment }\end{array}$} & $\begin{array}{l}\text { Equal } \\
\text { variances } \\
\text { assumed }\end{array}$ & 7.98 & .01 & 7.05 & 24 & .00 & 1.25 & .18 & .88 & 1.62 \\
\hline & $\begin{array}{l}\text { Equal } \\
\text { variances not } \\
\text { assumed }\end{array}$ & & & 7.05 & 12.85 & .00 & 1.25 & .18 & .87 & 1.63 \\
\hline \multirow{2}{*}{ Trust in leader } & $\begin{array}{l}\text { Equal } \\
\text { variances } \\
\text { assumed }\end{array}$ & 7.59 & .01 & 5.47 & 24 & .00 & 1.21 & .22 & .75 & 1.67 \\
\hline & $\begin{array}{l}\text { Equal } \\
\text { variances not } \\
\text { assumed }\end{array}$ & & & 5.47 & 13.50 & .00 & 1.21 & .22 & .74 & 1.69 \\
\hline \multirow{2}{*}{$\begin{array}{l}\text { Job } \\
\text { satisfaction }\end{array}$} & $\begin{array}{l}\text { Equal } \\
\text { variances } \\
\text { assumed }\end{array}$ & 3.15 & .09 & 2.78 & 24 & .01 & .68 & .24 & .17 & 1.18 \\
\hline & $\begin{array}{l}\text { Equal } \\
\text { variances not } \\
\text { assumed }\end{array}$ & & & 2.78 & 17.25 & .01 & .68 & .24 & .16 & 1.19 \\
\hline
\end{tabular}

According to Table 1 and Table 2, Group 1 and Group 2 each consist of 13 subjects. According to the results of the Levene's Test for Equality of Variances, equal variances are assumed for job satisfaction ( $\mathrm{p}>.05)$, and equal variances are not assumed for affective commitment $(\mathrm{p}<.05)$ and trust $(\mathrm{p}<.05)$. Independent samples t-test revealed that there is a significant difference between the two groups in terms of all the dependent variables of affective commitment $(\mathrm{t}=7.05, \mathrm{p}<.05)$, trust $(\mathrm{t}=5.47, \mathrm{p}<.05)$, and job satisfaction $(\mathrm{t}=2.78, \mathrm{p}<.05)$. 
In terms of affective commitment, trust, and job satisfaction, the mean values for Group 1 (3.16, 3.28, and 3.43, respectively) are significantly lower than the mean values of Group 2 (4.41, 4.49, and 4.11, respectively). Thus, hypotheses H1 (Negative emotional expressions by the leader (e.g. anger) moderate the relationship between leader-member exchange and follower affective commitment, where high LMX leaders who display negative emotional expressions will arouse less affective commitment by their followers as compared to high LMX leaders who do not), H3 (Negative emotional expressions by the leader (e.g. anger) moderate the relationship between leader member exchange and follower trust in leader, where high LMX leaders who display negative emotional expressions will arouse less trust by their followers as compared to high LMX leaders who do not), and H5 (Negative emotional expressions by the leader (e.g. anger) moderate the relationship between leader member exchange and follower job satisfaction, where high LMX leaders who display negative emotional expressions will arouse less job satisfaction by their followers as compared to high LMX leaders who do not) are supported.

Table 3 and Table 4 below show the group statistics and the independent samples t-test results for Group 3 and Group 4:

Table 3. Group Statistics for Group 3 (Angry Low LMX Leader) and Group 4 (Non-Angry Low LMX Leader)

\begin{tabular}{llcccr}
\hline Dependent variables & \multicolumn{1}{c}{ Groups } & N & Mean & Std. Deviation & Std. Error Mean \\
\hline \multirow{2}{*}{$\begin{array}{l}\text { Affective } \\
\text { commitment }\end{array}$} & $\begin{array}{l}\text { Angry low LMX } \\
\text { leader }\end{array}$ & 13 & 1.64 & .21 & .06 \\
\cline { 2 - 6 } & $\begin{array}{l}\text { Non-angry low } \\
\text { LMX leader }\end{array}$ & 13 & 2.13 & .54 & .15 \\
\hline \multirow{2}{*}{ Trust in leader } & $\begin{array}{l}\text { Angry low LMX } \\
\text { leader }\end{array}$ & 13 & 1.68 & .25 & .07 \\
\cline { 2 - 6 } & $\begin{array}{l}\text { Non-angry low } \\
\text { LMX leader }\end{array}$ & 13 & 2.31 & .40 & .11 \\
\hline \multirow{2}{*}{ Job satisfaction } & $\begin{array}{l}\text { Angry low LMX } \\
\text { leader }\end{array}$ & 13 & 1.48 & .31 & .09 \\
\cline { 2 - 6 } & $\begin{array}{l}\text { Non-angry low } \\
\text { LMX leader }\end{array}$ & 13 & 1.98 & .49 & .14 \\
\hline
\end{tabular}


Table 4. Independent Samples t-Test Results for Group 3 (Angry Low LMX Leader) and Group 4 (Non-Angry Low LMX Leader)

\begin{tabular}{|c|c|c|c|c|c|c|c|c|c|c|}
\hline & & \multicolumn{2}{|c|}{$\begin{array}{c}\text { Levene's Test } \\
\text { for Equality of } \\
\text { Variances } \\
\end{array}$} & \multicolumn{7}{|c|}{ t-test for Equality of Means } \\
\hline & & \multirow[t]{2}{*}{$\mathrm{F}$} & \multirow[t]{2}{*}{ Sig. } & \multirow[t]{2}{*}{$\mathrm{t}$} & \multirow[t]{2}{*}{$\mathrm{df}$} & \multirow[t]{2}{*}{$\begin{array}{l}\text { Sig. (2- } \\
\text { tailed) }\end{array}$} & \multirow[t]{2}{*}{$\begin{array}{l}\text { Mean } \\
\text { Diff. }\end{array}$} & \multirow[t]{2}{*}{$\begin{array}{l}\text { Std. } \\
\text { Error } \\
\text { Diff. }\end{array}$} & \multicolumn{2}{|c|}{$\begin{array}{l}95 \% \text { Confidence } \\
\text { Interval of the } \\
\text { Difference }\end{array}$} \\
\hline & & & & & & & & & Lower & Upper \\
\hline \multirow{2}{*}{$\begin{array}{l}\text { Affective } \\
\text { commitment }\end{array}$} & $\begin{array}{l}\text { Equal } \\
\text { variances } \\
\text { assumed }\end{array}$ & 6.66 & .02 & 3.02 & 24 & .01 & .48 & .16 & .15 & .81 \\
\hline & $\begin{array}{l}\text { Equal } \\
\text { variances not } \\
\text { assumed }\end{array}$ & & & 3.02 & 15.59 & .01 & .48 & .16 & .14 & .82 \\
\hline \multirow{2}{*}{$\begin{array}{l}\text { Trust in } \\
\text { leader }\end{array}$} & $\begin{array}{l}\text { Equal } \\
\text { variances } \\
\text { assumed }\end{array}$ & 1.32 & .26 & 4.78 & 24 & .00 & .63 & .13 & .36 & .89 \\
\hline & $\begin{array}{l}\text { Equal } \\
\text { variances not } \\
\text { assumed }\end{array}$ & & & 4.78 & 20.37 & .00 & .63 & .13 & .35 & .90 \\
\hline \multirow{2}{*}{$\begin{array}{l}\text { Job } \\
\text { satisfaction }\end{array}$} & $\begin{array}{l}\text { Equal } \\
\text { variances } \\
\text { assumed } \\
\end{array}$ & 2.61 & .12 & 3.14 & 24 & .00 & .51 & .16 & .18 & .84 \\
\hline & $\begin{array}{l}\text { Equal } \\
\text { variances not } \\
\text { assumed }\end{array}$ & & & 3.14 & 20.26 & .01 & .51 & .16 & .17 & .84 \\
\hline
\end{tabular}

As Table 3 and Table 4 display, Group 3 and Group 4 each are composed of 13 subjects. According to the results of the Levene's Test for Equality of Variances, equal variances are assumed for trust $(\mathrm{p}>.05)$ and job satisfaction $(\mathrm{p}>.05)$, and equal variances are not assumed for affective commitment $(\mathrm{p}<.05)$. Independent samples $\mathrm{t}$-test revealed that there is a significant difference between the two groups in terms of all the dependent variables of affective commitment $(\mathrm{t}=3.02, \mathrm{p}<.05)$, trust $(\mathrm{t}=4.78, \mathrm{p}<.05)$, and job satisfaction $(\mathrm{t}=3.14, \mathrm{p}<.05)$. In terms of all the dependent variables of affective commitment, trust, and job satisfaction, the mean values for Group $3(1.64,1.68$, and 1.48 , respectively) are significantly lower than the mean values for Group 4 (2.13, 2.31, and 1.98, respectively). Thus, hypotheses H2 (Negative emotional expressions by the leader (e.g. anger) moderate the relationship between leader member exchange (LMX) and follower affective commitment, where low LMX leaders who display negative emotional expressions will arouse less affective commitment by their followers as compared to low LMX leaders who do not), H4 (Negative emotional expressions by the leader (e.g. anger) moderate the relationship between leader member exchange (LMX) and follower trust in leader, where low LMX leaders who display negative emotional expressions will arouse less trust by their followers as compared to low LMX leaders who do not), and H6 (Negative emotional expressions by the leader (e.g. anger) moderate the 
relationship between leader member exchange (LMX) and follower job satisfaction, where low LMX leaders who display negative emotional expressions will arouse less job satisfaction by their followers as compared to low LMX leaders who do not) are supported.

\section{CONCLUSION}

As hypothesized and found in $\mathrm{H} 1, \mathrm{H} 3$, and H5, negative emotional expressions by the leader (e.g. anger) moderate the relationship between leader member exchange and job outcomes of affective commitment, trust in leader, and job satisfaction, respectively, in such a way that high LMX leaders who display negative emotional expressions will arouse less affective commitment, trust, and job satisfaction by their followers as compared to high LMX leaders who do not. Here, the expression of a negative emotion such as anger neutralizes the positive effect of leader member exchange on follower job outcomes, due to the fact that followers who witness a strong negative emotion like anger coming from a leader they are in a close relationship with, may become irritated and this irritation may negatively influence their job outcomes.

As hypothesized and found in $\mathrm{H} 2, \mathrm{H} 4$, and $\mathrm{H} 6$, negative emotional expressions by the leader (e.g. anger) moderate the relationship between leader member exchange (LMX) and follower job outcomes of affective commitment, trust in leader, and job satisfaction, respectively, in such a way that low LMX leaders who display negative emotional expressions will arouse less affective commitment, trust, and job satisfaction by their followers as compared to low LMX leaders who do not. Here, the expression of a negative emotion by a low LMX leader worsens the negative image of this leader in the eyes of the followers, and therefore has a more negative effect on their job outcomes compared to a low LMX leader who acts neutral.

This research contributes to the leadership and emotions literatures by explaining the moderating effect of one discrete negative emotion, which is in our case anger, on the direct effect of leader-member exchange on job outcomes.

Previous research suggests that the expression of negative emotions by leaders have further negative impacts on the image of leaders. For instance, according to the findings of a study undertaken by Lewis (2000), negative emotional displays of anger and sadness had a significant negative effect on the assessment of leader effectiveness by followers. Further, Van Kleef, Homan, Beersma, and van Knippenberg (2010) put forth that anger is associated with hostility and conflict. Research undertaken by Madera and Smith (2009) reveals that in a crisis situation, leader emotional expressivity of anger led to participant negative affect which was 
negatively associated with leader evaluation. Another experimental study by Gaddis, Connelly, and Mumford (2004) highlights that negative leader affect brought about lower perceptions of leader effectiveness and lower quality performance on a group task. Last but not the least, Newcombe and Ashkanasy (2002) found that positive leader affect results in more positive ratings of the leader compared to negative leader affect.

In the light of the previous studies discussed above and in parallel to the findings of this study, the author suggests that the expressivity of anger by high LMX leaders might cancel out their positive image in the eyes of their followers and therefore have a negative effect on their job outcomes. This can be explained by the fact that because negative emotions bring about an avoidance tendency, followers may be inclined to distance themselves from the leader who is displaying negative emotions (Eberly\&Fong, 2013). In addition, followers react to the expressivity of anger by their leaders more strongly when they perceive these displays as inappropriate (Van Kleef et al., 2012).Therefore, the expression of anger coming from high LMX leaders is contrary to the image of these leaders and therefore will be perceived as inappropriate by their followers.

This research is, to the author's knowledge, the first to bring the concepts of leader member exchange and leader emotional expressivity of anger together, and therefore shall contribute to the progress of leadership research.

As to the limitations of this research, it is a cross-sectional study, therefore data pertaining to the long term of the hypothesized relationships are not present. Secondly, all the data is collected from Istanbul, Turkey. Therefore, findings of this research might bear an effect of the Turkish culture and therefore limit the generalizability of the findings. Accordingly, the author suggests that the same study can be undertaken in different cultural contexts. 


\section{REFERENCES}

Akkaya, T. (2015). Lider-üye etkileşiminin iş doyumuna etkisinde örgütsel iklimin rolü: Hizmet sektöründe bir lojistik şirket uygulaması (Doctoral thesis, HaliçÜniversitesi, Istanbul, Turkey). Retrieved from https://tez.yok.gov.tr/UlusalTezMerkezi/tezSorguSonucYeni.jsp

Allen, N. J., \& Meyer, J. P. (1990). The measurement and antecedents of affective, continuance and normative commitment to the organization. Journal of Occupational Psychology, 63, 1-18.

Baker, N. (2018). Leader-member exchange and follower trust in leader: The moderating effect of leader emotional expressivity. International Journal of Social Sciences and Education Research, 4(4), 741-749.

Brayfield, A., \&Rothe, H. (1951). An index of job satisfaction. Journal of Applied Psychology, 35, 307-311.

Bulut, M. Ş. (2012). Lider-üye etkileşiminin yöneticiye güven ve iş tatmini üzerine etkisinin araştırllması: Öğretmenler üzerine bir araştırma (Master's thesis, YeditepeÜniversitesi, Istanbul, Turkey). Retrieved from https://tez.yok.gov.tr/UlusalTezMerkezi/tezSorguSonucYeni.jsp

Dansereau, F., Graen, G., \& Haga, W. J. (1975). A vertical dyad linkage approach to leadership within formal organizations. Organizational Behavior and Human Performance, 13(1), 46-78.

Dasborough, M.T. (2006). Cognitive asymmetry in employee emotional reactions to leadership behaviors. The Leadership Quarterly, 17, 163-178.

Eberly, M. B., \& Fong, C. T. (2013). Leading via the heart and mind: The roles of leader and follower emotions, attributions and interdependence. The Leadership Quarterly, 24, 696-711.

Elfenbein, H. (2007). Emotion in organizations: A review and theoretical integration. The Academy of Management Annals, 1(1), 315-386.

Fitness J. (2000). Anger in the workplace: an emotion script approach to anger episodes between workers and their superiors, coworkers and subordinates. Journal of Organizational Behavior, 21, 147-162.

Gaddis, B., Connelly, S., \& Mumford, M. D. (2004). Failure feedback as an affective event: Influence of leader affect on subordinate attitude and performance. The Leadership Quarterly, 15, 663-686.

Gardner, W. L., Fischer, D., \& Hunt, J. G. (2009). Emotional labor and leadership: A threat to authenticity? The Leadership Quarterly, 20, 466-482.

George, J. M. (2000). Emotions and leadership: The role of emotional intelligence. Human Relations, 53, 10271055.

Gibson, D. E., \& Callister, R. R. (2010). Anger in organizations: Review and integration. Journal of Management, 36(1), 66-93.

Glomb, T. M., \& Hulin, C. L. (1997). Anger and gender effects in observed supervisor-subordinate dyadic interactions. Organizational Behavior and Human Decision Processes, 72, 281-307.

Goleman, D. (1998). Working with Emotional Intelligence. Bantam Books: New York. 
Graen, G. B., \&Uhl-Bien, M. (1995). Relationship-based approach to leadership: Development of leader-member exchange (LMX) theory of leadership over 25 years: Applying a multi-level multi-domain perspective. The Leadership Quarterly, 6, 219-247.

Hair, J. F., Black, W. C., Babin, B. J., Anderson, R. E., \& Tatham, R. L. (2010). Multivariate data analysis. New Jersey: Prentice Hall.

Inelmen, K. (2009). Role of trust in mediating the effects of satisfaction and commitment on employee performance. Boğaziçi Journal, 23(1-2), 55-73.

Janssens, W., Wijnen, K., De Pelsmacker, P., \& Van Kenhove, P. (2008). Marketing Research with SPSS. New York: Prentice Hall Financial Times.

Judge, T. A., Locke, E. A., Durham, C., \& Kluger, A. N. (1998). Dispositional Effects on Job and Life Satisfaction: The Role of Core Evaluations, Journal of Applied Psychology, 83, 17-34.

Kant, L., Skogstad, A., Torsheim, T., \& Einarsen, S. (2013). Beware the angry leader: Trait anger and trait anxiety as predictors of petty tyranny. The Leadership Quarterly, 24(1), 106-124.

Kirkpatrick, S. A., \& Locke, E. A. (1991). Leadership: do traits matter? Academy of Management Executive, 5, 48-60.

Lelieveld, G., Van Dijk, E., Van Beest, I., \& Van Kleef, G. A. (2012). Why anger and disappointment affect other's bargaining behavior differently: The moderating role of power and the mediating role of reciprocal and complementary emotions. Personality and Social Psychology Bulletin, 38(9), 1209-1221.

Lerner, J. S., \&Tiedens, L. Z. (2006). Portrait of the angry decision maker: How appraisal tendencies shape anger's influence on cognition. Journal of Behavioral Decision Making, 19(2), 115-137.

Lewis, K. M. (2000). When leaders display emotion: How followers respond to negative emotional expression of male and female leaders. Journal of Organizational Behavior, 21, 221-234.

Locke, E.A. (1976). The cause and nature of job satisfaction. In M.D. Dunnette (Ed.), Handbook of industrial and organizational psychology (pp. 1297-1349). Chicago, IL: Rand McNally.

Madera, J. M., \& Smith, D. B. (2009). The effects of leader negative emotions on evaluations of leadership in a crisis situation: The role of anger and sadness. The Leadership Quarterly, 20(2), 103-114.

Meyer, J. P., Allen, N. J., \& Smith, C. A. (1993). Commitment to organizations and occupations: Extension and test of a three-component conceptualization. Journal of Applied Psychology, 78, 538-551.

Newcombe, M. J., \& Ashkanasy, N. M. (2002). The role of affect and affective congruence in perceptions of leaders: An experimental study. The Leadership Quarterly, 13, 601-614.

Rafaeli, A., \& Sutton, R. I. (1987). Expression of emotion as part of the work role. Academy of Management Review, 12, 23-37.

Rousseau, D. M., Sitkin, S. B., Burt, R. S., \& Camerer, C. (1998). Not so different after all: A cross-discipline view of trust. Academy of Management Review, 23, 393-404.

Spielberger, C. D. (1988). Professional manual for the State-Trait Anger Expression Inventory. Odessa FL: Psychological Assessment resources. 
Sy, T., Côté, S., \& Saavedra, R. (2005). The contagious leader: Impact of the leader's mood on the mood of group members, group affective tone, and group processes. Journal of Applied Psychology, 90, 295-305.

Şirin, E. (2012). Kişilik, lider-üye etkileşimi ve çalışan sonuçları (Master’s thesis, Gebze Yüksek Teknoloji Enstitüsü, Gebze, Turkey). Retrieved from https://tez.yok.gov.tr/UlusalTezMerkezi/tezSorguSonucYeni.jsp

Tiedens, L. Z. (2001). Anger and advancement versus sadness and subjugation: The effect of negative emotion expressions on social status conferral. Journal of Personality and Social Psychology, 80, 86-94.

Ülker, F. (2015). Lider-üye etkileşimi ve çallşan tutumları üzerindeki etkisi: Ĕ̈itim sektöründe bir uygulama (Master's thesis, Kocaeli Üniversitesi, Kocaeli, Turkey). Retrieved from https://tez.yok.gov.tr/UlusalTezMerkezi/tezSorguSonucYeni.jsp

Van Kleef, G. A. (2009). How emotions regulate social life: The emotions as social information (EASI) model. Current Directions in Psychological Science, 18, 184-188.

Van Kleef, G. A., \& Cote, S. (2007). Expressing anger in conflict: When it helps and when it hurts. Journal of Applied Psychology, 92(6), 1557-1569.

Van Kleef, G. A., Homan, A. C., Beersma, B., van Knippenberg, D., van Knippenberg, B., \& Damen, F. (2009). Searing sentiment or cold calculation? The effects of leader emotional displays on team performance depend on follower epistemic motivation. Academy of Management Journal, 52(3), 562-580.

Van Kleef, G. A., Homan, A. C., Beersma, B., \& van Knippenberg, D. (2010). On angry leaders and agreeable followers: How leaders' emotions and followers' personalities shape motivation and team performance. Psychological Science, 21(12), 1827-1834.

Van Kleef, G. A., Homan, A. C., \& Cheshin, A. (2012). Emotional influence at work: Take it EASI. Organizational Psychology Review, 2, 311-339.

Waldman, D. A., Balthazard, P. A., \& Peterson, S. J. (2011). Leadership and neuroscience: Can we revolutionize the way that inspirational leaders are identified and developed? Academy ofManagement Perspectives, 25(1), $60-74$.

Wubben, M. J., De Cremer, D., \& Van Dijk, E. (2009). How emotion communication guides reciprocity: Establishing cooperation through disappointment and anger. Journal of Experimental Social Psychology, 45(4), 987-990.

Yukl, G. A. (2005). Leadership in organizations $\left(6^{\text {th }}\right.$ ed.). New York: Prentice Hall. 